\title{
Dental Journal
}

\section{Dental Journal \\ (Majalah Kedokteran Gigi) \\ 2017 September; 50(3): 111-115}

\section{Correlation between reactive oxygen species and oral conditions in elderly individuals with hypertension: a preliminary study}

\author{
Nanan Nur'aeny, Wahyu Hidayat, and Indah Suasani Wahyuni \\ Department of Oral Medicine \\ Faculty of Dentistry, Universitas Padjadjaran \\ Bandung - Indonesia
}

\begin{abstract}
Background: The increased number of elderly people in Indonesia can be a positive phenomenon if their health is well-preserved. The elderly are influenced by physiological changes, environmental factors, and personal habits making them susceptible to chronic diseases. The oral cavity is also subject to change, one of the causes being reduced salivary flow that is manifested in dental caries and other oral health concerns. This disease is stimulated by oxidative stress in the body due to an imbalance between reactive oxygen species (ROS) and the antioxidant defense system. Purpose: This preliminary study aimed to investigate ROS-related hypertension and the state of oral health of elderly patients. Methods: The study constitutes a combination of cross-sectional observation and consecutive sampling. Twelve subjects, selected on the basis of inclusive and exclusive criteria, consisted of two males and ten females. Physical examinations and blood sampling were performed on all subjects. $R$ version 3.4.1 for Windows operating system was used to perform statistical tests. Results: The 12 patients shared a history of hypertension, the lowest ROS level was 0.87 IU/ml, while the highest was one of $7.20 \mathrm{IU} / \mathrm{ml}$. The correlation between ROS and oral conditions showed only ROS and tooth loss as having a significant positive correlation. An independent t test showed there to be a mean difference between ROS with Miyazaki index 1 and 2 but it was statistically insignificant. Conclusion: There was no correlation between the ROS level in the bloodstream and general oral health, except in the relationship between the ROS level in the bloodstream and tooth loss which had a positive correlation.
\end{abstract}

Keywords: reactive oxygen species; hypertension; oral condition; elderly

Correspondence: Nanan Nur'aeny, Department of Oral Medicine, Faculty of Dentistry, Universitas Padjadjaran. Jl. Sekeloa Selatan no. 1 Bandung 40132, Indonesia. E-mail: nanan.nuraeny@fkg.unpad.ac.id.

\section{INTRODUCTION}

The increased number of elderly people in Indonesia could be a positive phenomenon if their health can be wellpreserved. The elderly are influenced by physiological changes, environmental factors, and personal habits making them susceptible to chronic diseases, such as hypertension. ${ }^{1}$ The oral cavity might also experience such conditions due to reduced salivary flow that is manifested in dental caries, dry mouth, and numerous other symptoms. ${ }^{2}$ The human body undergoes a metabolic process involving internal and external stimuli. The external stimuli include lifestyle and personal habits. Data from Riset Kesehatan Dasar (Riskesdas) in 2013 showed the frequency of brushing their teeth among a group of elderly people to be low. Such neglect might result in poor oral hygiene and, ultimately, as is the case with the elderly who experience a high incidence of the condition, tooth loss. ${ }^{3}$ A coated tongue is also often found in the elderly due to decreased efficiency of the salivary glands resulting from degenerative conditions and others factors including: systemic condition, drugs, or dietary habits. ${ }^{4}$

All processes in the elderly could generate free radicals in the cell as a consequence of enzymatic and nonenzymatic reactions. Free radicals represent any molecular species capable of independent existence that contains unpaired electrons in an atomic orbital. ${ }^{5}$ A mitochondria cell is an internal source of free radicals, released as a 
by-product of energy metabolism when cells produce adenosine tri phosphate (ATP). This by-product is generally a reactive oxygen species (ROS) which plays a dual role as both a toxic and beneficial compound and is crucial to human physiological and pathophysiological processes. ${ }^{6,7}$ At low or moderate levels, ROS exerts a beneficial effect on cellular responses and immune functions. With regard to host defence, ROS contributes directly and indirectly to the killing of microorganisms. ${ }^{8}$ At high concentrations, they generate oxidative stress. This constitutes a deleterious process potentially prejudicial to the entire cell structure, including: lipids, membranes, protein and DNA. ${ }^{9}$ Progressive aging is associated with higher levels of oxidative biomolecules reacting with free radicals. ${ }^{10}$ The progress of a pathologic condition is stimulated by oxidative stress in the body due to an imbalance between ROS and an antioxidant defense system. ${ }^{11}$ Research into ROS in elderly patients in Indonesia, particularly regarding its relation to changes within the oral cavity, has not been widely conducted. Thus, the purpose of this preliminary study is to investigate ROS-related hypertension and oral cavity conditions in elderly patients.

\section{MATERIALS AND METHODS}

This study constitutes a cross-sectional observation and consecutive sampling conducted at the Community Health Center, Ujung Berung, Bandung. The observers were members of the research team $(n=3)$. The inclusion criteria applied to all patients consisted of the following: male or female, aged 60 years or above, registered as a patient at the Ujung Berung Community Health Center, a history of hypertension, and a willingness to provide signed confirmation of informed consent. The exclusion criteria comprised: oral candidiasis lesions, oral leukoplakia, multiple ulceration of the tongue, and pre-cancerous ulcer lesions. Twelve subjects fitting the inclusion and exclusion criteria included two males and ten females. Oral examination and blood sampling were performed on the subjects, from whom $5 \mathrm{ml}$ of blood was taken for ROS examination at the Clinical Pathology Laboratorium, Hasan Sadikin Hospital. R version 3.4.1 for Windows operating system was used to conduct statistical tests, all of which were performed to a significance level of 0.05 . The research reported here received ethical approval from the Health Research Ethics Committee, Universitas Padjadjaran, number 754/UN6.C.10/PN/2017, and registration number: 0817050696.

\section{RESULTS}

This preliminary study involved the participation of 12 elderly patients with a history of hypertension (Table 1 and Table 2). A Spearman correlation was calculated to measure the correlation between systolic and diastolic
ROS (Figure 1a and Figure 1b). Oral cavity anomalies were found to include dental caries, tooth necrosis, plaque and calculus, dental filling, tooth root, tooth loss, and coated tongue (Table 3). The lowest ROS level was $0.87 \mathrm{IU} / \mathrm{ml}$, while the highest stood at $7.20 \mathrm{IU} / \mathrm{ml}$ (Table 4). There was no correlation between the ROS level in the bloodstream and general oral health, except in the relationship of the ROS level in the bloodstream and tooth loss which demonstrated a significant correlation $(p=0.028)$ (Figure 1c-1f). An independent t test showed that there was a mean difference between ROS and the Miyazaki index 1 and 2, but this was not considered to be statistically significant (Figure 1g). Clinically, a coated tongue was defined as one with a white-yellowish layer equals in size to one- to two-thirds the area of the posterior dorsum of the tongue (Figure 2a and 2b).

\section{DISCUSSION}

This research was a preliminary study conducted on a small group of elderly people aged between 60 and 79 years, with the majority falling within the 60-69 years age range. According to the Badan Pusat Statistik (BPS), the life expectancy of members of West Java's population continues to increase and in the period 2015-2020 is anticipated to reach 72.8 years. ${ }^{12}$ The definition of who constitutes an elderly or geriatric person is based on broad and varied age ranges. Nevertheless, a common classification system would include: a lower range (65-74 years), a middle range (75-85 years), and an upper range ( $>85$ years). ${ }^{2,13}$ A limited amount of data in this study (Table 1) showed scant difference between the lower and middle range groups, with the number of females higher than that of males. According to the BPS, females enjoy a higher life expectancy than males. ${ }^{12}$

Table 1. Characteristics of patients $(n=12)$

\begin{tabular}{ccc}
\hline No. & Characteristics & $\mathrm{n}$ \\
\hline 1. & Age range & \\
& $60-69$ & 7 \\
& $70-79$ & 5 \\
2. & Gender & \\
& Female & 10 \\
& Male & 2 \\
\hline
\end{tabular}

Table 2. Blood pressure category

\begin{tabular}{clll}
\hline No. & Category & \multicolumn{1}{r}{ Blood pressure $(\mathrm{mmHg})$} & $\mathrm{n}$ \\
\hline 1. & High normal & $130-139$ and/or $85-89$ & 2 \\
2. & Mild & $140-159$ and/or $90-99$ & 5 \\
3. & Moderate & $160-179$ and/or $100-109$ & 3 \\
4. & Severe & $\geq 180$ and/or $\geq 110$ & 2 \\
\hline
\end{tabular}


Table 3. Oral conditions of patients

\begin{tabular}{|c|c|c|c|c|c|c|c|}
\hline No. & $\begin{array}{l}\text { Dental } \\
\text { caries* }\end{array}$ & $\begin{array}{c}\text { Tooth } \\
\text { necrosis* }\end{array}$ & $\begin{array}{l}\text { Tooth } \\
\text { loss* }\end{array}$ & Filling & Plaque/Calculus** & $\begin{array}{l}\text { Tooth } \\
\text { root* }\end{array}$ & $\begin{array}{c}\text { Index coated } \\
\text { tongue } * * *\end{array}$ \\
\hline 1 & 2 & 1 & 2 & none & exist & 2 & 2 \\
\hline 2 & none & none & 4 & none & exist & 3 & 2 \\
\hline 3 & none & none & 7 & none & exist & 2 & 2 \\
\hline 4 & 3 & none & 10 & none & exist & 3 & 1 \\
\hline 5 & none & 3 & 10 & none & exist & 3 & 2 \\
\hline 6 & 6 & none & 4 & none & exist & 2 & 2 \\
\hline 7 & 4 & none & 6 & none & exist & 3 & 2 \\
\hline 8 & none & none & 6 & none & exist & 4 & 1 \\
\hline 9 & 1 & none & 5 & none & exist & 2 & 1 \\
\hline 10 & none & none & 9 & none & exist & 7 & 1 \\
\hline 11 & none & 2 & 3 & none & exist & 1 & 2 \\
\hline 12 & 1 & none & 2 & none & exist & 1 & 1 \\
\hline
\end{tabular}

Note: * Number of tooth

** Exist $=$ by visual, at least plaque or calculus found in one site of tooth

*** Index Miyazaki; score $0=$ not visible, score $1=<1 / 3$ surface of the tongue covered, score $2=<2 / 3$ surface of the tongue covered, and score $3=>2 / 3$ the surface of the tongue is covered.
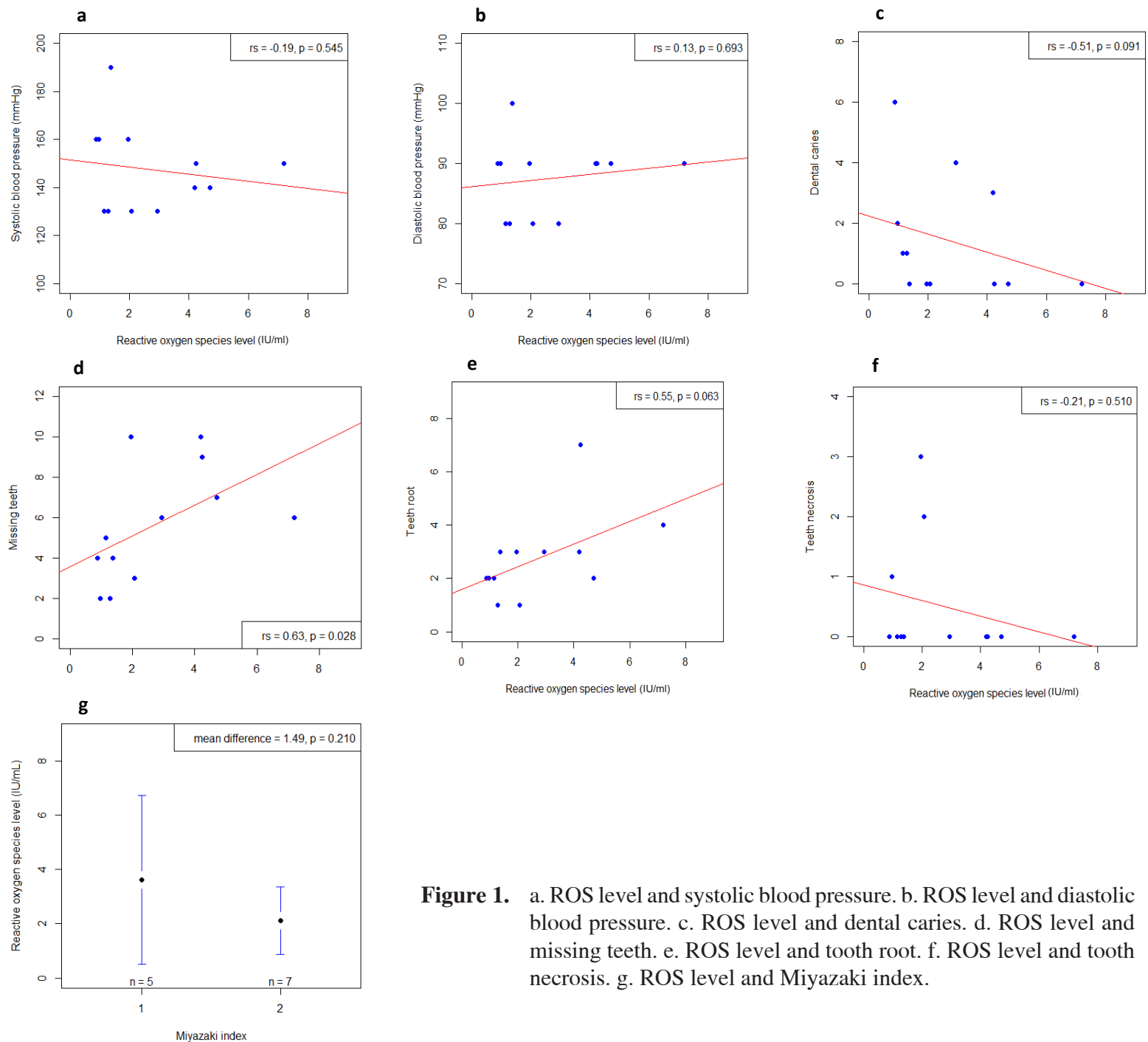

Figure 1. a. ROS level and systolic blood pressure. b. ROS level and diastolic blood pressure. c. ROS level and dental caries. d. ROS level and missing teeth. e. ROS level and tooth root. f. ROS level and tooth necrosis. g. ROS level and Miyazaki index. 
Table 4. Characteristics of patients and ROS level

\begin{tabular}{cccc}
\hline No. & Age (years) & Gender & $\begin{array}{c}\text { ROS } \\
\text { level (IU/ml) }\end{array}$ \\
\hline 1. & 64 & Male & 0.95 \\
2. & 60 & Female & 1.37 \\
3. & 69 & Male & 4.71 \\
4. & 73 & Female & 4,2 \\
5. & 65 & Female & 1,94 \\
6. & 73 & Female & 0.87 \\
7. & 77 & Male & 2.94 \\
8. & 73 & Female & 7.2 \\
9. & 73 & Female & 1.14 \\
10. & 62 & Female & 4.24 \\
11. & 64 & Female & 2.07 \\
12. & 64 & Female & 1.28 \\
\hline
\end{tabular}
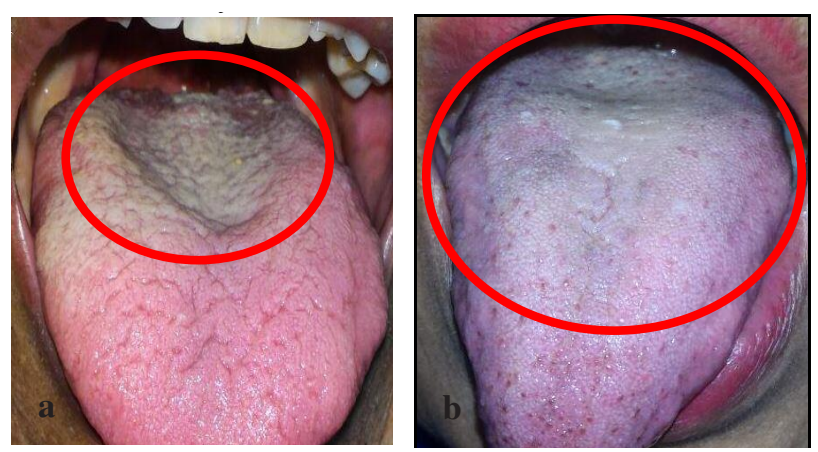

Figure 2. a. $1 / 3$ coated section of the tongue; b. $2 / 3$ coated section of the tongue

Aging is simply the result of accumulative deteriorative processes such as oxidation. ${ }^{14}$ Biological functions gradually decline with age and may be due to one or more of the following factors: lifestyle, behaviour, diet, and environment. ${ }^{14}$ Oxidants or free radicals are generated internally as a result of normal intracellular metabolism in mitochondria and peroxisomes, as well as from a variety of cytosolic enzyme systems whereas, externally, ROS production is triggered by a certain agent within an indvidual's lifestyle and/or environment. ${ }^{15}$ Aging is a natural and progressive process producing functional changes in the body due to aforementioned internal and external factors that might manifest themselves as a chronic condition such as hypertension. In this study, patients' blood pressure largely fell within the mild category (systolic $=140-159$ and/or diastolic $=90-99 \mathrm{mmHg}$ ). A test of the correlation between ROS and systolic blood pressure levels confirmed it to be negative (Figure 1) but there was a positive diastolic and ROS correlation (Figure 2). According to the study described here, ROS levels were within the lower range, this result being in line with the studies indicating that, in a mild hypertension condition, lipid peroxidation and oxidative stress levels are not increased. ${ }^{16,17}$
Oxidative stress promotes smooth vascular muscle cell proliferation, together with hypertrophy and collagen deposition leading to thickening of the vascular media and narrowing of the vascular lumen. In addition, increased oxidative stress may damage the endothelium and impair endothelium-dependent vascular relaxation and increase vascular contractile activity. All these effects on the vasculature may explain how increased oxidative stress can cause hypertension. ${ }^{18}$ This result confirmed all patients to have been well cared for as they had received routine monthly treatment from a health programme (chronic disease management program) at the Community Health Center,Ujung Berung, Bandung. Such treatment usually included the implementation of a dietary regime. The dietary approaches to ttop hypertension (DASH) study confirmed that the DASH diet, which was rich in vegetables, fruits and low-fat dairy products, low in fat, and including whole grains, poultry, fish and nuts, and lowered blood pressure. ${ }^{19}$ Other results confirmed the correlation between ROS and diastolic levels in this study as positive. Although this study did not feature a complete data history of hypertension, the theory mentions the potential occurrence of this condition because ROS potentially results in hypertension by inducing vascular contraction (Figure 2) ${ }^{20}$ It is known that superoxide (ROS) rapidly deactivates endotheliumderived nitric oxide (NO), the most important endogenous vasodilator, thereby promoting vasoconstriction. ${ }^{21}$

Intra-oral findings showed most cases to be dental caries, tooth loss, plaque/calculus, and tooth root. The correlation only produced positive and significant results for ROS and tooth loss, at $\mathrm{p}=0.028$ (Figure 4). This possibly happened due to the presence of remnants of ROS related to previous infections or conditions triggering tooth loss, supported by the presence of plaque and calculus in all patients. This, in turn, meant that there were some forms of gingival inflammation (gingivitis or periodontitis) which induced increased ROS in tooth loss. ${ }^{22}$ Other conditions produced a negative correlation between ROS for dental caries and tooth necrosis, meaning that when dental caries and tooth necrosis decrease, the level of ROS increases. However, this condition requires further investigation involving a greater number of research subjects. Oral mucosa conditions also produced a coated tongue, a clinical condition in which a white yellowish layer forms on the dorsum of the tongue caused by the accumulation of food debris, microorganisms, desquamated epithelial cel/keratin, pigment, and mucus. Several factors are suspected of being associated with a coated tongue, including: chemotherapy, allergies, vitamin deficiency, radiation therapy, poor oral hygiene, salivary $\mathrm{pH}$ change, decreased salivary production, systemic disease, and drug consumption. ${ }^{14}$ Clinically, according to the Miyazaki index, the coated tongue of the majority of patients (7) registered a score of 2, signifying that the layer covered an area two-thirds the size of the posterior of the tongue. The $t$ test result showed that the mean difference between ROS and the Miyazaki index was higher in a group with score 1 than score 2 . The data 
showed that all patients who recorded a score of 2 also presented considerable tooth loss, plaque, and calculus, thereby indicating poor oral hygiene and, probably, a soft diet resulting in the accumulation of debris on the tongue. Decreased salivary flow as physiologic changes occur in elderly might also influence the occurrence of a coated tongue. ${ }^{4}$ In this study, there was no oral manifestation related with antihypertension drugs, such as xerostomia, lichenoid reactions, burning mouth syndrome, or stomatitis. ${ }^{15}$ In conclusion, there was no correlation between the ROS level in the bloodstream and general oral conditions, except in the relationship between the ROS level in the bloodstream and tooth loss which had a positive correlation.

\section{ACKNOWLEDGEMENT}

This study was supported by internal grant funding from Universitas Padjadjaran and thanks to the Dermatomusculoskeletal (DMS) study center of Faculty of Medicine Universitas Padjadjaran which has provided an opportunity for the implementation of this research.

\section{REFERENCES}

1. Veiga N, Domingues A, Douglas F, Rios S, Vaz A, Coelho C, Bexiga $\mathrm{F}$, Coelho I. The influence of chronic diseases in the oral health of the elderly. J Dent Oral Health. 2016; 2: 1-6.

2. Razak PA, Richard KMJ, Thankachan RP, Hafiz KAA, Kumar KN, Sameer KM. Geriatric oral health: a review article. J Int Oral Health. 2014; 6(6): 110-6.

3. Kementerian Kesehatan Republik Indonesia. Riset Kesehatan Dasar (RISKESDAS 2013). Jakarta: Badan Penelitian dan Pengembangan Kesehatan Kementerian Kesehatan RI; 2013. p. 1-384.

4. Nur'aeny N, Sari KI. Profil lesi mulut pada kelompok lanjut usia di panti sosial Tresna Wreda Senjarawi Bandung. Maj Ked Gi Ind. 2016; 2(2): 74-9.

5. Lobo V, Patil A, Phatak A, Chandra N. Free radicals, antioxidant and functional foods: impact on human health. Pharmacogn Rev. 2010; 4(8): 118-26.
6. Pham-Huy LA, He H, Pham-Huy C. Free radicals, antioxidants in disease and health. Int J Biomed Sci. 2008; 4(2): 89-96.

7. D'Autréaux B, Toledano MB. ROS as signalling molecules: mechanisms that generate specificity in ROS homeostasis. Nat Rev Mol Cell Biol. 2007; 8: 813-24.

8. Brieger K, Schiavone S, Miller Jr FJ, Krause K. Reactive oxygen species: from health to disease. Swiss Med Wkly. 2012; 142: 1-14.

9. Valko M, Leibfritz D, Moncol J, Cronin MTD, Mazur M, Telser J. Free radicals and antioxidants in normal physiological functions and human disease. Int J Biochem Cell Biol. 2007; 39: 44-84.

10. Oliveira BF, Nogueira-Machado JA, Chaves MM. The role of oxidative stress in the aging process. Sci World J. 2010; 10: 1121-8.

11. Mohammed MT, Kadhim SM, Jassimand AMN, Abbas SI. Free radicals and human health. Int J Innov Sci Res. 2015; 4(6): 218-23.

12. Badan Perencanaan Pembangunan Nasional, Badan Pusat Statistik, United Nations Population Fund. Proyeksi penduduk Indonesia: Indonesia population projection 2010-2035. Jakarta: Badan Pusat Statistik; 2013. p. 32-4.

13. Gates BJ, Walker KM. Physiological changes in older adults and their effect on diabetes treatment. Diabetes Spectr. 2014; 27(1): 20-9.

14. Goldsmith TC. An introduction to biological aging theory. $2^{\text {nd }}$ ed. Crownsville: Azinet Press; 2014. p. 45.

15. Rahman T, Hosen I, Islam MMT, Shekhar HU. Oxidative stress and human health. Adv Biosci Biotechnol. 2012; 3: 997-1019.

16. National Heart Foundation of Australia. Guideline for the diagnosis and management of hypertension in adults 2016. Melbourne: National Heart Foundation of Australia; 2016. p. 74.

17. Touyz RM, Briones AM. Reactive oxygen species and vascular biology: implications in human hypertension. Hypertens Res. 2011; 34: 5-14.

18. Logan AC, Wong C. Chronic fatigue syndrome: oxidative stress and dietary modifications. Altern Med Rev. 2001; 6(5): 450-9.

19. Vasdev S, Singal P, Gill V. The antihypertensive effect of cysteine. Int J Angiol. 2009; 18(1): 7-21.

20. Lassègue $B$, Griendling KK. Reactive oxygen species in hypertension: an update. Am J Hypertens. 2004; 17: 852-60.

21. Rodrigo R, Prat H, Passalcqua W, Araya J, Guichard C, Bächler JP. Relationship between oxidative stress and essential hypertension. Hypertens Res. 2007; 30: 1159-67.

22. Leong X, Ng C, Badiah B, Das S. Association between hypertension and periodontitis: possible mechanisms. Sci World J. 2014; 2014: $1-11$. 